\title{
Is there any Relationship between Normal Blood Glucose Level and Foot's Second Finger?
}

\author{
Muhammad Imran Qadir, Hira Baig* \\ Institute of Molecular Biology and Biotechnology, Bahauddin Zakariya University, Multan, Pakistan \\ *Corresponding Author: Hira Baig, Institute of Molecular Biology and Biotechnology, Bahauddin \\ Zakariya University, Multan, Pakistan
}

\begin{abstract}
The main purpose of the recent study to analyze or to check whether blood glucose level in humans have any relation with size of the foot's second finger. Total of 115 subjects participated in this research article. Subjects were students of Bahauddin Zakariya University Multan, Pakistan. To check the blood glucose level, first wash the hand completely, and then prick your finger with needle, blood released out and then collected the blood with strip that is attached to the glucose meter and then glucose meter showed the glucose level in the body on the screen. Study that based on questionnaire always played a vital role in research study. This survey proved that there is no relationship between the blood glucose level and size of second finger of foot
\end{abstract}

Keywords: Blood glucose level, questionnaire, prick

\section{INTRODUCTION}

The sugar level in the blood is the quantity of sugar in the blood. It is measured in mill moles per liter. Blood glucose level is measured to monitor or to check the diabetes. With the increase of age it becomes important to keep an eye on the blood glucose level, also regulate it during pregnancy. The main source of energy is the carbohydrate. We take carbohydrates as a source of energy, when carbohydrates digested it breaks down for the formation of glucose (sugar) in the bloodstream. There are factors that affect the glucose level in the blood. Alcohol, caffeine, protein, fat, carbohydrates, dose that we take for recovery, time for taking dose, exercise, smoking, allergies, insufficient etc. . it is necessary to keep healthy of yourself even in diabetes by regulating the sugar level in the blood. Less than $100 \mathrm{mg} / \mathrm{dL}$ in fasting comes under the normal range of glucose in the blood. Level of glucose 70 to $80 \mathrm{mg} / \mathrm{dL}$ is the also normal range for diabetic patient. Level of sugar that exceeds or decrease from normal range considered as unhealthy. People with diabetes should do exercise it is very beneficial to manage the level of glucose in the blood. Glucose meter is a device that or check the sugar level in the blood. Glucose meters are of different types. Hypoglycemia is a condition when level of sugar falls from normal rang. To Keep very low sugar level in the blood, without having diabetes, also a condition of pre diabetes. This hypoglycemia called reactive hypoglycemia. When glucose level exceeds the condition is called hyperglycemia. In this condition glucose level elevated and comes under the range of $180-200 \mathrm{mg} / \mathrm{dL}$.

Some people have large metatarsal bone and some have small, due to long metatarsal bone foot's second finger large, due to small metatarsal foot's second finger also small. There are many facts that have been write down about second finger of foot. People with large second finger of foot have qualitative characteristics and play leading roles in their relationships. India and China wrote on foot readings. Indian mothers now strictly forbidden their sons to marry with the girls those have large second finger (1-2).

The main purpose of the recent study to analyze or to check whether blood glucose level in humans have any relation with size of the foot's second finger.

\section{MATERIALS AND MeTHODS}

Total of 115 subjects participated in this research article. Subjects were students of Bahauddin Zakariya University Multan, Pakistan. 


\subsection{Project Designing}

To check the blood glucose level, first wash the hand completely, and then prick your finger with needle, blood released out and then collected the blood with strip that is attached to the glucose meter and then glucose meter showed the glucose level in the body on the screen

\subsection{Statistical Analysis}

Statistical analysis were performed or analyze by the use M-Stat and by the used of t-Test

\section{RESUltS}

Table \#1 showed that the relation between the blood glucose level and size of second finger of foot

Level of blood glucose Average and standard deviation in males those had second bigger finger of foot, were 87.2 and 10.99 respectively and in males with smaller finger was 63.4 and 54.84 respectively with $\mathrm{p}$ value 0.53 . Level of blood glucose in females had bigger and smaller finger of foot were had average and standard deviation $86.6,85$ and $7.84,6.93$ respectively with $p$ value 0.32 . People with both males and females had blood glucose level with average and standard deviation $86.7,82.5$ and $7.94,18.24$ respectively with second bigger and smaller finger of foot than thumb, with $\mathrm{p}$ value 0.08 .

\begin{tabular}{|l|l|l|l|}
\hline Gender & Bigger finger of foot & Second finger of foot & P value \\
\hline Male & $87.2 \pm 10.99$ & $63.4 \pm 54.84$ & 0.53 \\
\hline Female & $86.6 \pm 7.84$ & $85 \pm 6.93$ & 0.32 \\
\hline Combined & $86.7 \pm 7.94$ & $82.5 \pm 18.24$ & 0.08 \\
\hline
\end{tabular}

P> 0.05 (non-significant)

\section{DISCUSSION}

Study that based on questionnaire always played a vital role in research study (3-6). Many papers had been written on the blood glucose level. Glucose serves as the energy production for tissues. There are many hormones that regulate glucose such as growth hormones. Glucagon and epinephrine produce a defense mechanism in both cases if the blood glucose level is high or low

20-30 \% population in the world had bigger second finger of foot, to having a second bigger finger of foot is totally normal, hypothesis made about the larger and smaller finger of foot

\section{CONCLUSION}

This survey proved that there is no relationship between the blood glucose level and size of second finger of foot

\section{REFERENCES}

[1] Content taken from the Canadian Diabetes Association's consumer fact sheets, Managing Blood Glucose and Lows and Highs: Blood Glucose Levels.

[2] Canadian diabetes association Managing your blood glucose

[3] Qadir MI, Ishfaq S (2018) Awareness about hypertension in biology students. Int J Mod Pharma Res, 7(2): 08-10.

[4] Qadir MI, Mehwish (2018) Awareness about psoriasis disease. Int J Mod Pharma Ress, 2(1): 14-16.

[5] Qadir MI, Ghalia BA (2018) Awareness survey about colorectal cancer in students of M. Phil Biotechnology at BahauddinZakariya University, Multan, Pakistan. Nov Appro in Can Study, 1(3): NACS. 000514.2018.

[6] Qadir MI, Saba G (2018) Awareness about intestinal cancer in university student. Nov Appro in Can Study, 1(3): NACS.000515.2018

Citation: Muhammad Imran Qadir, Hira Baig, "Is there any Relationship between Normal Blood Glucose Level and Foot's Second Finger?" International Journal of Research Studies In Biosciences (Ijrsb), Vol. 7, no. 7, pp. 23-24, 2019. http://Dx.Doi.org/10.20431/2349-0365.0707005

Copyright: (ㅇ 2019 Authors. This is an open-access article distributed under the terms of the Creative Commons Attribution License, which permits unrestricted use, distribution, and reproduction in any medium, provided the original author and source are credited. 